\title{
Effect of Licorice Mouthwash on Xerostomia among Hemodialysis Patients
}

\author{
Heba Elsayed Khatab, Lecturer \\ Medical Surgical Nursing, Faculty of Nursing, Alexandria University
}

\begin{abstract}
Most patients with end-stage renal disease (ESRD) undergoing hemodialysis had complaints as thirst, xerostomia and saliva reduction. These complications can be due to; high sodium intake, potassium depletion, increased blood urea, increased blood sugar, high angiotensin II (Ang II) levels, as well as psychological factors. Licorice is used for treating upper respiratory problems as coughs, hoarseness, sore throat, mouth ulcer and dry mouth. Objective: Determine the effect of licorice mouthwash on xerostomia for patients undergoing hemodialysis. Setting: The study was conducted in Hemodialysis Department, Ras- Elteen General Hospital. Subjects: A convenience sample of 44 patients-fulfilling the inclusion criteria were involved. Tools: Two tools were used to collect the necessary data; tool I: Hemodialysis Patients' Assessment, and tool II: Xerostomia Inventory Assessment Tool. Results: $90.9 \%$ of study group had improvement in their salivary secretion. This indicated that patient who used licorice mouth wash had lower xerostomia than those who did not. Conclusion: Licorice mouth wash was effective in reducing xerostomia for patients undergoing hemodialysis. Recommendations: Licorice mouth wash could be used as an intervention to reduce xerostomia for patients undergoing hemodialysis.
\end{abstract}

Keywords: Licorice; Hemodialysis; Xerostomia.

\section{Introduction}

The kidneys play an essential role in the maintenance of hemostasis by their capacity to remove metabolic waste products, electrolytes and water from the body. End stage renal disease (ESRD) occurs when the function of the kidneys is impaired $5-10 \%$ of the original capacity. It is defined as a reduction in glomerular filtration rate (GFR), and decreased creatinin clearance rate. The incidence of patients with ESRD in 2001 reached 100 per million. It increases with age and male individuals are more commonly affected than females ${ }^{(1)}$. Patients with ESRD can rely on kidney replacement therapeutic modalities such as hemodialysis (HD), peritoneal dialysis (PD) or renal transplantation (NTx). In general, HD treatment is done on a regular basis (performed every 2-3 days for 4-5 hours). In PD treatment the patient's peritoneal membrane is used as an artificial kidney, where sterile dialysis fluid is introduced into the abdominal cavity for several hours, drained and refreshed several times a day. As for kidney transplantation, it is done to restore normal function and homeostasis of the renal function ${ }^{(1)}$. Hemodialysis is the most commonly used method of dialysis; more than 300,000 Americans currently receive hemodialysis. It is used for acutely ill patients who require short-term dialysis (days to weeks) and for those with ESRD requiring long-term or permanent therapy ${ }^{(2)}$.

Most patients with end-stage renal disease (ESRD) undergoing hemodialysis develop multiple complications as; cardiovascular disease, hypertension, acute pulmonary edema, and congestive heart failure. Researchers found that a considerable number of maintenance hemodialysis (MHD) patients suffer from thirst, xerostomia and saliva reduction. These complications are due to high sodium intake, potassium depletion, increased blood urea, increased blood sugar, high angiotensin II (Ang II) levels, and psychological factors $^{(3,4)}$. Saliva has a wide variety of physiological and biological processes. This includes cleansing and lubricating of oral soft and hard tissues, maintenance of dental and mucosal integrity, solubilization and bolus formation of food, facilitation of taste perception, mastication, speech, and retention of removable 
prostheses $^{(5,6)}$. Salivary gland-hypo function or hypo-salivation is the condition of having reduced saliva production due to various causes. It usually leads to the subjective complaint of oral dryness termed Xerostomia $^{(7)}$.

The term Xerostomia comes from the Greek word xeros (dry) and stoma (mouth). It is defined as the subjective feelings of a dry mouth. It is a common symptom in hemodialysis patients, associated with a reduced salivary flow. It has widespread implications as impaired quality of life, poor oral health, oral pain, impaired speech, inability chew, swallow, rampant dental caries, oral fungal infections (as candidiasis), taste changes, and burning sensation in mouth ${ }^{(4,7-10)}$. The prevalence of xerostomia and salivary gland hypo-function is very difficult to determine. In 2006, it was found that the prevalence of self-reported xerostomia ranged $0.9 \%-64.8 \%$. It was also estimated that $30 \%$ of the population aged 65 years or older suffered from these disorders $^{(11)}$.

However, the prevalence reaches almost $100 \%$ in patients with Sjögren's syndrome as well as those who are on radiation therapy for head and neck cancer. Moreover, the prevalence increased with age and it seemed more in postmenopausal women compared to men. Xerostomia may be also a problem for a minority of young patients in their early thirties. It is special to those on antidepressants, they are 22 times higher in risk $^{(7)}$. Licorice, it is the name given to the roots and stolons of Glycyrrhiza species. It has been used since ancient times as a traditional herbal remedy. The genus name Glycyrrhiza is derived from the ancient Greek words glycos (meaning sweet) and rhiza (meaning root) ${ }^{(12)}$. Historically, the dried rhizome and root of this plant were used expectorant and carminative medicinally by the Egyptian, Chinese, Greek, Indian, as well as Roman civilizations. Licorice is most common medical use is treating upper respiratory problems as coughs, hoarseness, sore throat and bronchitis. It has also antibacterial, antioxidant, antimalarial, antispasmodic anti-inflammatory and anti-hyper glycemic properties. Licorice extracts have been used for more than 60 years in Japan to treat chronic hepatitis. It has also therapeutic benefit against other viruses as human immunodeficiency virus (HIV), cytomegalovirus (CMV), and Herpes simplex $^{(12,13)}$.

Furthermore, the Deglycyrrhizinated licorice (DGL) preparations are useful in treating various types of ulcers. Topical licorice preparations have been used to sooth and heal skin eruptions; as psoriasis and herpetic lesions. Licorice root (Glycyrrhiza extract) are found in the form of a small, oral patch to relieve pain and accelerate healing of canker sores ${ }^{(13,14)}$. Licorice root is available under various forms as candies, capsules, tablets, liquid extracts ${ }^{(12)}$. The safe amount of licorice root to be used depends on body weight as well as pre-existing health conditions and life stage. Pregnant, nursing women and people with estrogensensitive diseases should not eat licorice ${ }^{(15)}$. Licorice being a sweet-tasting substance and acting as a gustatory stimulus may increase the salivary flow thus have a beneficial impact against dental caries ${ }^{(12)}$.

It was found that those with mouth ulcer and gargled using licorice mouth wash 4 times per day had their pain relieved. A mouthwash containing licorice provided relief from mouth ulcer in $75 \%$ of people using it ${ }^{(14)}$. Oral hygiene is one of the basic needs of both sick and well people. It is essential that nurses recognize its importance and understand that delivering effective oral hygiene is a skilled nursing activity. Care of the mouth is considered one of the most basic nursing activities. Nurses must be more meticulous in choosing mouthwash for their patients. Frequent using mouthwash has been highlighted as the most important aspect of oral mouth care $^{(15,16)}$. 


\section{Aim of the Study}

The present study was conducted to determine the effect of licorice mouthwash on xerostomia among hemodialysis patients.

\section{Research Hypothesis}

Licorice mouthwash decreases xerostomia and enhances saliva secretion in patients undergoing hemodialysis?

\section{Materials and Method}

\section{Materials}

Design: A quasi experimental design was used to conduct this study.

Setting: The study was conducted in the Hemodialysis Department, Ras Elteen General Hospital.

Subjects: A convenience sample of 44 patients, admitted to the hemodialysis unit, complaining of xerostomia.

\section{$\underline{\text { Tools: }}$}

Tool I: Hemodialysis Patients' Assessment

It was developed by the researcher after review of relevant literature. It was used to assess hemodialysis patient's oral health status before and after using the mouthwash. It consisted of two parts.

Part I: Patient's socio-demographic data and clinical $\operatorname{data}^{(17)}$ :

It included patients' socio demographic data; age, gender, education, occupation, marital status and area of residence. Clinical data were medical diagnosis, as well as medical history as; duration of hemodialysis, past history, associated disease, and prescribed current treatment/ medication.

\section{Part II: Oral health assessment tool $\left(\right.$ OHAT) ${ }^{(18-20)}$ :}

It was adopted from Thomson (1999), and Song (2013). It included 8 parameters for oral health with a total score of 16 . Each parameter was scored on a 3-Likert scale 02. The lower scores indicated better condition. The scores were as follows:
- $0=$ Healthy.

- $1=$ Changes

- 2 = Unhealthy.

Tool II: Xerostomia Inventory Assessment Tool

It was adopted from Thomson (1999) ${ }^{(18)}$. It was made of 11questions to assess level of xerostomia. Each question was scored against a 5-Likert scale 1="never", 2="hardly ever", 3="Occasionally", $4=$ =fairly often", and 5="very often". It was used the $1^{\text {st }}$ day as a base line data, and ${ }^{5 \text { th }}$ day after using of licorice mouth wash.

\section{Method}

- An official letter was obtained from the administrative office-Faculty of Nursing.

- A written approval was obtained from the hospital administrators and head of the hemodialysis unit, after explanation of the study aim.

- The study tool I (part I) was developed by the researcher after a thorough review of relevant literature.

- Tools I (part II), and tool II were adopted.

- To test the content validity of the tools, they were submitted to 5 experts in Medical Surgical Nursing.

- $28 \mathrm{gm}$ of sliced licorice roots were boiled for 10 minutes in $450 \mathrm{ml}$ of distilled water. The solution was then dissolved in $400 \mathrm{ml}$ fluid. The final licorice mouth wash was packed in $100 \mathrm{ml}$ plastic bottle. Each patient in the study group was given after consent, the product (licorice mouth wash). They were instructed that to shake the bottle prior to use. It should be used 3 times per day after each meal. The follow- up was after 5 days of treatment to assess xerostomia, and mouth dryness 
- Reliability of the study tool II (OHAT) was estimated using (Cronbach's Alpha test 0.759) and for the Xerostomia Inventory Assessment Tool it was 0.912 .

- A Pilot study was conducted on 5 patients for testing clarity, feasibility and applicability of the study tools, and they were excluded from the sample subjects.

- Forty-four adult patients on hemodialysis were recruited and assigned randomly into two equal groups as follows:

- Group (I) was on the routine hospital treatment regimen.

- Group (II) was using a licorice mouth wash.

- An initial assessment was done using tools I, tool II for both groups.

- Each patient in both groups (study and control group) was interviewed, using the tools I, II pre intervention and then reevaluated on the $5^{\text {th }}$ day after intervention using the same tools.

\section{Ethical considerations:}

The researcher introduced herself to every studied patient, included in the study, explained the purpose of the study, and patient's informed consent to participate in the study was obtained. Every patient was informed that anonymity, confidentiality, and privacy would be assured.

\section{Statistical Analysis}

- Reliability test was measured by Cronbach's Alpha test. The oral health assessment tool (OHAT) tool was 0.759. Xerostomia Inventory Assessment Tool was 0.912 .

- After data collection, the raw data were coded and entered into SPSS system files (SPSS package version 20). Analysis and interpretation of data were conducted.

\section{The following statistical measures were used:}

- Descriptive statistics as frequency, distribution, mean, and standard deviation were used to describe different characteristics.

- Univariate analyses; t-test and paired t-test were used to test the significance of results of quantitative variables and to compare the means between two unrelated groups on the same continuous, dependent variable.

- The Friedman test as non-parametric test alternative to the one-way ANOVA with repeated measures. It was used to test for differences between groups as the dependent variable being measured was ordinal. It was used to test the significance of results of quantitative variables of abnormal distribution.

- The level of significance in this study $\mathrm{p}$ value was equal to or less than 0.05 .

\section{Results}

Table (1) shows distribution of the studied subjects according to their Sociodemographic characteristics. Regarding patients' age, the results revealed that the highest percentage of patients in the study and control groups $45.5 \%$, were among 40 $>50$ years old in the study group, and 60 years and more in the control group. In relation to patients' gender, the highest percentage of patients $59.1 \%$ in the study group were males, while in the control group were females. As regards the marital status, the highest percentage of patients in the study and control groups were married 77.3 $\%$ and $86.4 \%$ respectively. As for the educational level the highest percentage of patients in the study and control groups were illiterate $40.9 \%$ and $63.6 \%$ respectively. As regards occupation, the highest percentage of patients in the study and control groups were housewives, $40.9 \%$ and $59.1 \%$ respectively. Regarding area of residence, the highest percentage of patients in the 
study and control groups lived in urban areas $86.4 \%$ and $90.9 \%$ respectively.

Table (2) shows distribution of the studied subjects according to their health history. Duration of hemodialysis for the majority of patients in both study and control groups $77.3 \%$ and $86.4 \%$ respectively, was $\geq 12$ months. In additions the highest percentage in both study and control groups $54.5 \%$ and $77.3 \%$ respectively, had previous hospitalization. Regarding the associated diseases, the highest percentages in both study and control groups $63.6 \%$ and 86.4 respectively complained of other diseases. $78.6 \%$ of the study group, and all of the control group suffered from hypertension. While the lowest percentage $7.1 \%$ in the study group had endocrine disease, and $5.3 \%$ in the control group had drug allergy. Furthermore, $95.5 \%$ of both study and control groups were on anticoagulant medication. Only $4.5 \%$ in the study group were on endocrine medication, and $9.1 \%$ in the control group were on cardiac medications.

Table (3) shows distribution of the studied subjects according to their oral health assessment findings based on Oral Health Assessment Tool (OHAT). Regarding oral health assessment, the majority of patient's in both study and control groups $90.9 \%$ had lip changes on the $1^{\text {st }}$ assessment. This percent is changed in the study group to $100 \%$ healthy lip on the $5^{\text {th }}$ day after using licorice mouthwash. In addition, more than half of them in both study and control groups $72.7 \%$ and $73.2 \%$ respectively, had tongue changes. This became healthy tongue in the study group in $95.5 \%$ of the patients after 5 days of using licorice mouthwash. In relation to gums and tissue the percentage of both study and control groups in the $1^{\text {st }}$ day $77.3 \%$ and $68.2 \%$ respectively had gums and tissue changes. This became $90.9 \%$ in the study group as healthy gums and tissue after 5 days of using licorice mouth wash.

As regards saliva the majority of patients in both study and control groups $77.3 \%$ and
$86.4 \%$ in the $1^{\text {st }}$ assessment had saliva changes. It changed into healthy saliva in the study group in $90.9 \%$ after 5 days of using licorice mouth wash. Furthermore, $40.9 \%$ and $59.1 \%$ in both study groups had decayed teeth, and have no obvious changes after using mouthwash.

As regards denture, the majority of patients in both study and control groups $95.5 \%$ and $81.8 \%$ had no broken areas or teeth. Whereas, the minority of them in both study and control groups $4.5 \%$ had more than 1 broken area/ tooth, denture missing or not worn. In relation to oral cleanliness, the majority of patients in both study and control groups $(68.2 \%$ and $63.6 \%$ respectively), had changes in oral cleanliness (food particles/tartar/plaque in 12 areas of the mouth or on mall area of dentures or halitosis. The minority of them $(13.6 \%)$ in both study and control groups had unhealthy oral cleanliness. Furthermore, $22.7 \%$ in the study group on $5^{\text {th }}$ day after used licorice mouth wash had become healthy oral cleanness (clean and no food particles or tartar in mouth or dentures. Furthermore, dental pain, $27.3 \%$ of the study group in the $1^{\text {st }}$ day has complained of dental pain. It was $81.8 \%$ in the $5^{\text {th }}$ day after use of licorice mouth wash with no signs of dental pain.

Table (4) shows distribution of the studied subjects according to their mean percent score and standard deviation of oral health assessment findings based on Oral Health Assessment Tool (OHAT). This table showed mean percent score and standard deviation of oral health assessment findings based on Oral Health Assessment Tool (OHAT), there was a statistical significant differences in the study group between the $1^{\text {st }}$ day and $5^{\text {th }}$ day after using licorice mouthwash on Lips, tongue, gums and tissue, as well as saliva $\mathrm{p}=<0.001^{*}$, Oral cleanness $\mathrm{p}=0.046^{*}$, and Dental pain $\mathrm{p}=0.011 *$.

There was a statistical significant differences between the study and control groups on the $5^{\text {th }}$ day after using licorice 
mouthwash on Lips, tongue, gums and tissue, as well as saliva $\mathrm{p}=<0.001^{*}$, Oral cleanness $\mathrm{p}=0.041^{*}$, and Dental pain $\mathrm{p}=<0.001 *$.

Table (5) shows distribution of the studied subjects (study group) according to their Xerostomia Inventory assessment findings based on Xerostomia Inventory Assessment Tool. This table showed the study group according to their Xerostomia Inventory assessment tool (OHAT), in the $1^{\text {st }}$ day Mean\% \pm SD 35.86 \pm 11.821 , and it became on the $5^{\text {th }}$ day after using licorice mouthwash Mean\% \pm SD 22.27 \pm 10.973 . There was a statistical significant differences between the $1^{\text {st }}$ day, and the $5^{\text {th }}$ day after using licorice mouthwash in the study group $\mathrm{p}=<0.003^{*}$.

Table (6) shows distribution of the studied subjects (control group) according to their Xerostomia Inventory assessment findings based on Xerostomia Inventory assessment tool (OHAT), in the $1^{\text {st }}$ day Mean\% \pm SD $35.41 \pm 11.632$, and in the $5^{\text {th }}$ day Mean $\% \pm$ SD 35.23 \pm 11.538 . There was no statistical significant differences between the 1 st day, and the $5^{\text {th }}$ day in the control group in which $\mathrm{p}=0.317$.

Table (7) shows distribution of the studied subjects according to their mean percent score and standard deviation of their Xerostomia Inventory assessment findings based on Xerostomia Inventory assessment tool. It was noticed that there were statistically significant differences between the $1^{\text {st }}$ day and $5^{\text {th }}$ day in the study patients, in relation to almost all the listed expected outcomes including; "I sip liquids to aid in swallowing food" as $\mathrm{p}=0.003^{*}$, "My mouth feels dry when eating a meal" as $\mathrm{p}=0.002^{*}$, "get up at night to drink" as $\mathrm{p}=<0.001 *$, "My mouth feels dry "as $p=0.002 *, "$ I have difficulty in eating dry foods" as $\mathrm{p}=<0.001^{*}$, "I suck sweets or lollies to relieve dry mouth" as $\mathrm{p}=0.018^{*}$, "I have difficulties swallowing certain foods" as $\mathrm{p}=<0.001^{*}$, "My lips feel dry" asp=0.020*, and "The inside of my nose feels dry", as $\mathrm{p}=0.034^{*}$
There were statistically significant differences between the $5^{\text {th }}$ day in the study and control groups after using licorice mouthwash, in relation to almost all the listed expected outcomes including; "I sip liquids to aid swallowing food, "My mouth feels dry when eating a meal", "get up at night to drink", "My mouth feels dry "," I have difficulty in eating dry foods" as $\mathrm{p}=<0.001^{*}$, "I suck sweets or lollies to relieve dry mouth" as $\mathrm{p}=0.004^{*}$, "I have difficulties swallowing certain foods" as $\mathrm{p}=0.001^{*}$, and "My lips feel dry" as $\mathrm{p}=0.029$.

\section{Discussion}

Xerostomia is the subjective feeling of a dry mouth. It is relatively common in patients on chronic hemodialysis. It can be caused by reduced salivary flow secondary to atrophy and fibrosis of the salivary glands $s^{(21,22)}$. In patients undergoing hemodialysis, restricted fluid results in xerostomia, this dryness in mouth makes patients more prone to bad breath, gum disease, tooth decay and tooth loss. Dry mouth and gum disease can make it harder to eat, thus resulting in malnutrition.

The findings of the present study showed that the majority of the studied patients in the study group were 40 to $>50$ years old, while the control group were 60 years old and more. In this context, Yang $(2008)^{(21)}$ stated that the age groups of 45-65, 65-75 and $>75$ years had almost the highest incidence and prevalence of ESRD.

The present study revealed that males comprised higher population than females in study group. This finding was congruent with Carrero $(2010)^{(23)}$, Iseki $(2008)^{(24)}$, who stated that women more protected from developing ESRD, while men had associated with a worse CKD progression than women, and loss of renal function was slower in women than in men, especially in women who were younger and premenopausal.

It was found that the majority of the studied patients in both groups were married. These findings are in contrast with 
Short ridge and James (2010) who stated that marriage and marital status might be protective for ESRD patients ${ }^{(25)}$.

The present findings showed that majority of the studied patients in both groups were illiterate, and housewives. This finding came in line with Adjei and Stronks $(2017)^{(26)}$ they found that low level of education and occupation were associated with worse kidney outcomes.

In the current study, it has been noticed that the majority of the studied patients in both groups were coming from urban areas. This result contradicts the results of Rodriguez (2013) ${ }^{(27)}$ who found that patients from rural areas were more at risk for kidney diseases due to long travel times and sparse renal services as transplant and dialysis centers.

Considering the associated diseases, the current study declared that about more than two third of the patients had hypertension. In this context Monhart (2013) ${ }^{(28)}$, and Tedla $(2011)^{(29)}$ stated that CKD was the most common cause of secondary hypertension, and it was extremely common among patients on hemodialysis or peritoneal dialysis. This was caused by disturbance in vasoactive substances, activation/insufficient suppression of vasoconstriction systems (renin-angiotensin-aldosterone, sympathetic system) and decreased production of vasodilator agents (e.g. prostaglandins).

Considering the oral health assessment findings based on oral health assessment tool (OHAT), the current study results elicited a statistically significant improvement of all its items (lips, tongue, gums, saliva, natural teeth, dentures, oral cleanness, and dental pain) on the $5^{\text {th }}$ day after using licorice mouthwash. This result was congruent with Messier et al. (2012) ${ }^{(11)}$ who stated that licorice being a sweet-tasting substance and acting as a gustatory stimulus might increase the salivary flow and then provide a beneficial impact against dental caries.
Interestingly, Touyz (2009) ${ }^{(30)}$ found that Licorice has systemic effects and local oral effects as allergic reactions, aphthous-like lesions, burning mouth syndrome, glossitis, ulcerations, erythema multiform, vesiculobullous lesions, color changes, oral lichenoid reactions, black hairy tongue, oral mucositis, gingival hyperplasia, salivary gland changes, dental changes, oral motor disorders, oral malodors, oral infections including osteonecrosis of the jaws, angioedema, and cheilitis.

\section{Conclusion}

Xerostomia affects patients' oral health and quality of life. The licorice mouthwash provided subjective relief of xerostomia. This suggested the use of a licorice mouthwash might effectively relieve feelings of dry mouth and enhances saliva secretion in patients undergoing hemodialysis.

\section{Recommendations}

- The nurse educates patients undergoing hemodialysis about mouth hygiene, xerostomia and dry mouth care.

- One family member should be taught mouth care and safe preparation of licorice mouth wash to help patient to follow the instructions in order to improve patient oral health outcome.

- Nurses should attend conferences and in service training program about care given to patients undergoing hemodialysis. 
Table (1): Distribution of the studied subjects according to their socio-demographic characteristics

\begin{tabular}{|c|c|c|c|c|}
\hline \multirow{2}{*}{ Socio-demographic characteristics } & \multicolumn{2}{|c|}{ Study group n(22) } & \multicolumn{2}{|c|}{ Control group n(22) } \\
\hline & No & $\%$ & No & $\%$ \\
\hline \multicolumn{5}{|l|}{ Age (Years) } \\
\hline $20>30$ & 0 & 0.0 & 1 & 4.5 \\
\hline $30>40$ & 3 & 13.6 & 2 & 9.1 \\
\hline $40>50$ & 10 & 45.5 & 0 & 0.0 \\
\hline $50>60$ & 3 & 13.6 & 9 & 40.9 \\
\hline 60 and more & 6 & 27.3 & 10 & 45.5 \\
\hline Minimum - Maximum & \multicolumn{2}{|c|}{ 34-71 years } & \multicolumn{2}{|c|}{$23-67$ years } \\
\hline Mean $\pm S D$ & \multicolumn{2}{|c|}{$51.5 \pm 10.6$ years } & \multicolumn{2}{|c|}{$54.4 \pm 10.5$ years } \\
\hline \multicolumn{5}{|l|}{ Gender } \\
\hline Male & 13 & 59.1 & 9 & 40.9 \\
\hline Female & 9 & 40.9 & 13 & 59.1 \\
\hline \multicolumn{5}{|l|}{ Marital status } \\
\hline Single & 3 & 13.6 & 1 & 4.5 \\
\hline Married & 17 & 77.3 & 19 & 86.4 \\
\hline Divorced & 1 & 4.5 & 1 & 4.5 \\
\hline Widow & 1 & 4.5 & 1 & 4.5 \\
\hline \multicolumn{5}{|l|}{ Level of education } \\
\hline Illiterate & 9 & 40.9 & 14 & 63.6 \\
\hline Read \&write & 4 & 18.2 & 4 & 18.2 \\
\hline Primary & 0 & 0.0 & 2 & 9.1 \\
\hline Secondary & 7 & 31.8 & 2 & 9.1 \\
\hline University & 2 & 9.1 & 0 & 0.0 \\
\hline \multicolumn{5}{|l|}{ Occupation } \\
\hline Laborer & 5 & 22.7 & 3 & 13.6 \\
\hline Professional & 1 & 4.5 & 0 & 0.0 \\
\hline Housewife & 9 & 40.9 & 13 & 59.1 \\
\hline Retired/ do not work & 7 & 31.8 & 6 & 27.3 \\
\hline \multicolumn{5}{|l|}{ Area of residence } \\
\hline Rural & 3 & 13.6 & 2 & 9.1 \\
\hline Urban & 19 & 86.4 & 20 & 90.9 \\
\hline
\end{tabular}


Table (2): Distribution of the studied subjects according to their health history

\begin{tabular}{|c|c|c|c|c|}
\hline \multirow{2}{*}{ Health History } & \multicolumn{2}{|c|}{ Study group n(22) } & \multicolumn{2}{|c|}{ "Control group n(22) } \\
\hline & No & $\%$ & No & $\%$ \\
\hline \multicolumn{5}{|l|}{ A. Present history } \\
\hline \multicolumn{5}{|l|}{ Duration of hemodialysis (months) } \\
\hline$\leq 3$ & 1 & 4.5 & 0 & 0.0 \\
\hline $3-6$ & 2 & 9.1 & 2 & 9.1 \\
\hline $6-12$ & 2 & 9.1 & 1 & 4.5 \\
\hline$\geq 12$ & 17 & 77.3 & 19 & 86.4 \\
\hline \multicolumn{5}{|l|}{ B. Past history } \\
\hline No past history & 5 & 22.7 & 3 & 13.6 \\
\hline Previous hospitalization & 10 & 45.5 & 17 & 77.3 \\
\hline previous hemodialysis & 7 & 31.8 & 0 & 0.0 \\
\hline previous peritoneal dialysis & 0 & 0.0 & 2 & 9.1 \\
\hline \multicolumn{5}{|l|}{ C. Associated disease } \\
\hline \multicolumn{5}{|l|}{ a- Complains of other diseases } \\
\hline No & 8 & 36.4 & 3 & 13.6 \\
\hline Yes & 14 & 63.6 & 19 & 86.4 \\
\hline b- Type of complains \# & n (14) & & n (19) & \\
\hline Hypertension & 11 & 78.6 & 19 & 100 \\
\hline DM & 6 & 42.9 & 5 & 26.3 \\
\hline IHD & 5 & 35.7 & 2 & 10.5 \\
\hline Endocrine disorder & 1 & 7.1 & 0 & 0.0 \\
\hline Drug allergy & 0 & 0.0 & 1 & 5.3 \\
\hline D. Prescribed current medications $\#$ & n (22) & & n (22) & \\
\hline No medication & 0 & 0.0 & 1 & 4.5 \\
\hline Endocrine medication & 1 & 4.5 & 0 & 0.0 \\
\hline Cardiac medications & 5 & 22.7 & 2 & 9.1 \\
\hline Hypoglycemic & 6 & 27.3 & 5 & 22.7 \\
\hline Antihypertensive & 11 & 50.0 & 18 & 81.8 \\
\hline Anticoagulant & 21 & 95.5 & 21 & 95.5 \\
\hline
\end{tabular}


Licorice Mouthwash, Xerostomia

Table (3): Distribution of the studied subjects according to their oral health assessment findings based on Oral Health Assessment Tool (OHAT)

\begin{tabular}{|c|c|c|c|c|c|c|c|c|}
\hline \multirow{3}{*}{ Oral Health Assessment Items } & \multicolumn{4}{|c|}{ Study group n(22) } & \multicolumn{4}{|c|}{ Control group n(22) } \\
\hline & \multicolumn{2}{|c|}{$\begin{array}{l}1^{\text {st }} \text { day (Baseline } \\
\text { Assessment) Scores }\end{array}$} & \multicolumn{2}{|c|}{$\begin{array}{c}5^{\text {th }} \text { day (Follow-up) } \\
\text { Scores }\end{array}$} & \multicolumn{2}{|c|}{$\begin{array}{l}1^{\text {st }} \text { day (Baseline } \\
\text { Assessment) Scores }\end{array}$} & \multicolumn{2}{|c|}{$\begin{array}{c}5^{\text {th }} \text { day (Follow-up) } \\
\text { Scores }\end{array}$} \\
\hline & No & $\%$ & $\mathrm{~N}_{0}$ & $\%$ & No & $\%$ & $\mathrm{~N}_{0}$ & $\%$ \\
\hline \multicolumn{9}{|l|}{ Lips } \\
\hline Healthy (smooth, pink, moist) & 0 & 0.0 & 22 & 100.0 & 1 & 4.5 & 1 & 4.5 \\
\hline Changes (dry chapped, or red at corners) & 20 & 90.9 & 0 & 0.0 & 20 & 90.9 & 20 & 90.9 \\
\hline $\begin{array}{l}\text { Unhealthy (swelling or lump, white/red/ulcerated patch; } \\
\text { bleeding/ulcerated at corners) }\end{array}$ & 2 & 9.1 & 0 & 0.0 & 1 & 4.5 & 1 & 4.5 \\
\hline \multicolumn{9}{|l|}{ Tongue } \\
\hline Healthy (normal, moist roughness, pink) & 3 & 13.6 & 21 & 95.5 & 2 & 9.1 & 2 & 9.1 \\
\hline Changes (patchy, fissured, red, coated) & 16 & 72.7 & 1 & 4.5 & 17 & 77.3 & 17 & 77.3 \\
\hline $\begin{array}{l}\text { Unhealthy (patch that is red and/or white, ulcerated, } \\
\text { swollen) }\end{array}$ & 3 & 13.6 & 0 & 0.0 & 3 & 13.6 & 3 & 13.6 \\
\hline \multicolumn{9}{|l|}{ Gums \&tissue } \\
\hline Healthy (pink, moist, smooth, no bleeding) & 3 & 13.6 & 20 & 90.9 & 5 & 22.7 & 4 & 18.2 \\
\hline $\begin{array}{l}\text { Changes (dry, shinny, rough, red, swollen, one ulcer/sore } \\
\text { spot under dentures) }\end{array}$ & 17 & 77.3 & 2 & 9.1 & 15 & 68.2 & 16 & 72.7 \\
\hline $\begin{array}{l}\text { Unhealthy (swollen, bleeding, ulcers, white/red patches, } \\
\text { generalized redness under dentures) }\end{array}$ & 2 & 9.1 & 0 & 0.0 & 2 & 9.1 & 2 & 9.1 \\
\hline \multicolumn{9}{|l|}{ Saliva } \\
\hline Healthy (moist tissues, watery and free flowing saliva) & 0 & 0.0 & 20 & 90.9 & 0 & 0.0 & 1 & 4.5 \\
\hline $\begin{array}{l}\text { Changes (dry, sticky tissues, little saliva present, resident } \\
\text { thinks they have a dry mouth) }\end{array}$ & 17 & 77.3 & 2 & 9.1 & 19 & 86.4 & 18 & 81.8 \\
\hline $\begin{array}{l}\text { Unhealthy (tissues parched and red, very little/no saliva } \\
\text { present, saliva is thick, resident thinks they have a dry } \\
\text { mouth) }\end{array}$ & 5 & 22.7 & 0 & 0.0 & 3 & 13.6 & 3 & 13.6 \\
\hline \multicolumn{9}{|l|}{ Natural teeth } \\
\hline Healthy (no decayed or broken teeth/roots) & 6 & 27.3 & 7 & 31.8 & 4 & 18.2 & 4 & 18.2 \\
\hline $\begin{array}{l}\text { Changes (1-3 decayed or broken teeth/ roots or very worn } \\
\text { down teeth) }\end{array}$ & 9 & 40.9 & 8 & 36.4 & 13 & 59.1 & 13 & 59.1 \\
\hline $\begin{array}{l}\text { Unhealthy }(4+\text { decayed or broken teeth/roots, or very worn } \\
\text { down teeth, or less than } 4 \text { teeth) }\end{array}$ & 7 & 31.8 & 7 & 31.8 & 5 & 22.7 & 5 & 22.7 \\
\hline
\end{tabular}


Licorice Mouthwash, Xerostomia

\begin{tabular}{|c|c|c|c|c|c|c|c|c|}
\hline \multirow{3}{*}{ Oral Health Assessment Items } & \multicolumn{4}{|c|}{ Study group n(22) } & \multicolumn{4}{|c|}{ Control group n(22) } \\
\hline & \multicolumn{2}{|c|}{$\begin{array}{l}1^{\text {st }} \text { day (Baseline } \\
\text { Assessment) Scores }\end{array}$} & \multicolumn{2}{|c|}{$\begin{array}{c}5^{\text {th }} \text { day (Follow-up) } \\
\text { Scores }\end{array}$} & \multicolumn{2}{|c|}{$\begin{array}{l}1^{\text {st }} \text { day (Baseline } \\
\text { Assessment) Scores }\end{array}$} & \multicolumn{2}{|c|}{$\begin{array}{c}5^{\text {th }} \text { day (Follow-up) } \\
\text { Scores }\end{array}$} \\
\hline & $\mathrm{N}_{0}$ & $\%$ & $\mathrm{~N}_{0}$ & $\%$ & $\mathrm{~N}_{0}$ & $\%$ & $\mathrm{~N}_{0}$ & $\%$ \\
\hline \multicolumn{9}{|l|}{ Denture } \\
\hline $\begin{array}{l}\text { Healthy (no broken areas or teeth, dentures regularly worn, } \\
\text { and named) }\end{array}$ & 21 & 95.5 & 21 & 95.5 & 18 & 81.8 & 18 & 81.8 \\
\hline $\begin{array}{l}\text { Changes ( } 1 \text { broken area/tooth or dentures only worn for } 1-2 \\
\text { hrs daily or dentures not named, or loose) }\end{array}$ & 0 & 0.0 & 0 & 0.0 & 3 & 13.6 & 3 & 13.6 \\
\hline $\begin{array}{l}\text { Unhealthy (more than } 1 \text { broken arealtooth, denture missing } \\
\text { or not worn, loose and needs denture adhesive, or not } \\
\text { named) }\end{array}$ & 1 & 4.5 & 1 & 4.5 & 1 & 4.5 & 1 & 4.5 \\
\hline \multicolumn{9}{|l|}{ Oral cleanness } \\
\hline $\begin{array}{l}\text { Healthy (clean and no food particles or tartar in mouth or } \\
\text { dentures) }\end{array}$ & 4 & 18.2 & 5 & 22.7 & 5 & 22.7 & 5 & 22.7 \\
\hline $\begin{array}{l}\text { Changes (food particles/tartar/plaque in 1-2 areas of the } \\
\text { mouth or on mall area of dentures or halitosis (bad breath)) }\end{array}$ & 15 & 68.2 & 17 & 77.3 & 14 & 63.6 & 14 & 63.6 \\
\hline $\begin{array}{l}\text { Unhealthy (food particles/tartar/plaque in most areas of the } \\
\text { mouth or on most of dentures or severe halitosis (bad } \\
\text { breath)) }\end{array}$ & 3 & 13.6 & 0 & 0.0 & 3 & 13.6 & 3 & 13.6 \\
\hline \multicolumn{9}{|l|}{ Dental pain } \\
\hline $\begin{array}{l}\begin{array}{l}\text { Healthy (no behavioral, verbal or physical signs of dental } \\
\text { pain) }\end{array} \\
\end{array}$ & 13 & 59.1 & 18 & 81.8 & 15 & 68.2 & 14 & 63.6 \\
\hline $\begin{array}{l}\text { Changes (are verbal \&/or behavioral signs of pain such as } \\
\text { pulling at face, chewing lips, not eating, aggression) }\end{array}$ & 3 & 13.6 & 4 & 18.2 & 7 & 31.8 & 7 & 31.8 \\
\hline $\begin{array}{l}\text { Unhealthy (are physical pain signs (swelling of cheek or } \\
\text { gum, broken teeth, ulcers), as well as verbal \&/or } \\
\text { behavioral signs (pulling at face, not eating, aggerssion)) }\end{array}$ & 6 & 27.3 & 0 & 0.0 & 0 & 0.0 & 1 & 4.5 \\
\hline
\end{tabular}


Licorice Mouthwash, Xerostomia

Table (4): Distribution of the studied subjects according to their mean percent score and standard deviation of oral health assessment findings based on Oral Health Assessment Tool (OHAT)

\begin{tabular}{|c|c|c|c|c|c|c|c|c|}
\hline \multirow{2}{*}{ Oral Health Assessment Items } & \multicolumn{2}{|c|}{ Study group n (22) } & \multicolumn{2}{|c|}{ Control group n (22) } & \multicolumn{4}{|c|}{ Test of significance } \\
\hline & Mean \% \pm SD & Mean \% \pm SD & Mean \% \pm SD & Mean \% $\%$ SD & P1 & P2 & P3 & P4 \\
\hline Lips sub score percent** & $54.55 \pm 14.71$ & $0.00 \pm .000$ & $50.00 \pm 15.43$ & $50.00 \pm 15.43$ & $<0.001^{*}$ & 1.00 & 0.329 & $<0.001 *$ \\
\hline Tongue sub score percent** & $50.00 \pm 26.72$ & $2.27 \pm 10.660$ & $52.27 \pm 24.28$ & $52.27 \pm 24.28$ & $<0.001 *$ & 1.00 & 0.789 & $<0.001 *$ \\
\hline Gums \&tissue sub score** percent & $47.73 \pm 24.28$ & $4.55 \pm 14.712$ & $43.18 \pm 28.01$ & $45.45 \pm 26.31$ & $<0.001^{*}$ & 0.317 & 0.576 & $<0.001 *$ \\
\hline Saliva sub score percent** & $61.36 \pm 21.44$ & $4.55 \pm 14.712$ & $56.82 \pm 17.56$ & $54.55 \pm 21.32$ & $<0.001 *$ & 0.317 & 0.427 & $<0.001 *$ \\
\hline Natural teeth sub score percent** & $52.27 \pm 39.27$ & $50.00 \pm 40.82$ & $52.27 \pm 32.65$ & $52.27 \pm 32.65$ & 0.317 & 1.00 & 1.00 & 0.847 \\
\hline Denture sub score percent** & $4.55 \pm 21.320$ & $4.55 \pm 21.320$ & $11.36 \pm 26.42$ & $11.36 \pm 26.42$ & 1.00 & 1.00 & 0.378 & 0.378 \\
\hline Oral cleanness sub score percent ${ }^{* *}$ & $47.73 \pm 28.77$ & $38.64 \pm 21.44$ & $45.45 \pm 30.50$ & $45.45 \pm 30.50$ & $0.046^{*}$ & 1.00 & 0.825 & $0.041^{*}$ \\
\hline \multirow[t]{2}{*}{ Dental pain sub score percent** } & $34.09 \pm 44.68$ & $9.09 \pm 19.739$ & $15.91 \pm 23.83$ & $20.45 \pm 29.51$ & $0.011^{*}$ & 0.317 & $0.011^{*}$ & $0.009 *$ \\
\hline & $\begin{array}{c}1^{\text {st }} \text { day } \\
\text { (Baseline } \\
\text { Assessment) } \\
\text { Scores } \\
\end{array}$ & $\begin{array}{c}5^{\text {th }} \text { day } \\
\text { (Follow-up) } \\
\text { Scores }\end{array}$ & $\begin{array}{c}1^{\text {st }} \text { day } \\
\text { (Baseline } \\
\text { Assessment) } \\
\text { Scores } \\
\end{array}$ & $\begin{array}{c}5^{\text {th }} \text { day } \\
\text { (Follow-up) } \\
\text { Scores }\end{array}$ & \multicolumn{2}{|c|}{ Friedman test } & \multicolumn{2}{|c|}{ t-test } \\
\hline Total score percent** & $44.03 \pm 16.42$ & $14.20 \pm 8.877$ & $40.91 \pm 14.39$ & $41.48 \pm 13.15$ & $<0.001 *$ & 0.317 & 0.518 & $<0.001 *$ \\
\hline
\end{tabular}

$p_{1}$ : Stands for p-value for Friedman test for comparison between $1^{\text {st }}$ day base line assessment with $5^{\text {th }}$ day follow-up assessment in the study group $p_{2}$ : Stands for p-value for Friedman test for comparison between $I^{\text {st }}$ day base line assessment with $5^{\text {th }}$ day follow-up assessment in the control group p:: p value for Student t-test for comparing $I^{\text {th }}$ day base line assessment between study and control group p4: p value for Student t-test for comparing $5^{\text {hi }}$ day follow-up assessment between study and control group

$*$ : Statistically significant at $p \leq 0.05 \quad$ **: Lower mean indicate better condition 
Licorice Mouthwash, Xerostomia

Table (5): Distribution of the studied subjects (study group) according to their Xerostomia Inventory assessment findings based on Xerostomia Inventory assessment tool (n 22)

\begin{tabular}{|c|c|c|c|c|c|c|c|c|c|c|c|c|c|c|c|c|c|c|c|c|c|c|}
\hline \multirow{3}{*}{$\begin{array}{l}\text { Xerostomia } \\
\text { Inventory } \\
\text { Assessment Items }\end{array}$} & \multicolumn{10}{|c|}{$1^{\text {st }}$ day (Baseline Assessment) } & \multicolumn{10}{|c|}{$5^{\text {th }}$ day (Follow-up) } & \multicolumn{2}{|c|}{$\begin{array}{c}\text { Test of } \\
\text { significance }\end{array}$} \\
\hline & \multicolumn{2}{|c|}{$\begin{array}{c}(1) \\
\text { Never }\end{array}$} & \multicolumn{2}{|c|}{$\begin{array}{c}(2) \\
\text { 'Hardly } \\
\text { ever' }\end{array}$} & \multicolumn{2}{|c|}{$\begin{array}{c}(3) \\
\text { 'Occasional } \\
\text { ly' }\end{array}$} & \multicolumn{2}{|c|}{$\begin{array}{c}\text { (4) } \\
\text { 'Fairly } \\
\text { often' }\end{array}$} & \multicolumn{2}{|c|}{$\begin{array}{c}(\mathbf{5}) \\
\text { 'Very } \\
\text { often' }\end{array}$} & \multicolumn{2}{|c|}{$\begin{array}{l}(1) \\
\text { Never }\end{array}$} & \multicolumn{2}{|c|}{$\begin{array}{c}(2) \\
\text { 'Hardly } \\
\text { ever' }\end{array}$} & \multicolumn{2}{|c|}{$\begin{array}{c}(3) \\
\text { 'Occasional } \\
\text { ly' }\end{array}$} & \multicolumn{2}{|c|}{$\begin{array}{c}\text { (4) } \\
\text { 'Fairly } \\
\text { often' }\end{array}$} & \multicolumn{2}{|c|}{$\begin{array}{c}(\mathbf{5}) \\
\text { 'Very } \\
\text { often' }\end{array}$} & \multirow[t]{2}{*}{$\begin{array}{l}\text { Fried- } \\
\text { man } \\
\text { test }\end{array}$} & \multirow[t]{2}{*}{$\begin{array}{c}\mathrm{P} \\
\text { value }\end{array}$} \\
\hline & No & $\%$ & No & $\%$ & $\mathrm{~N}_{0}$ & $\%$ & $\mathrm{~N}_{0}$ & $\%$ & No & $\%$ & No & $\%$ & $\mathrm{~N}_{0}$ & $\%$ & No & $\%$ & $\mathrm{~N}_{0}$ & $\%$ & $\mathrm{~N}_{0}$ & $\%$ & & \\
\hline $\begin{array}{l}\text { 1. I sip liquids to } \\
\text { aid in swallowing } \\
\text { food. }\end{array}$ & 6 & 27.3 & 0 & 0.0 & 7 & 31.8 & 1 & 4.5 & 8 & 36.4 & 13 & 59.1 & 0 & 0.0 & 6 & 27.3 & 3 & 13.6 & 0 & 0.0 & & \\
\hline $\begin{array}{l}\text { 2. My mouth feels } \\
\text { dry when eating a } \\
\text { meal. }\end{array}$ & 5 & 22.7 & 0 & 0.0 & 4 & 18.2 & 4 & 18.2 & 9 & 40.9 & 11 & 50.0 & 0 & 0.0 & 9 & 40.9 & 2 & 9.1 & 0 & 0.0 & & \\
\hline $\begin{array}{l}\text { 3. Get up at night } \\
\text { to drink. }\end{array}$ & 2 & 9.1 & 0 & 0.0 & 6 & 27.3 & 2 & 9.1 & 12 & 54.5 & 10 & 45.5 & 0 & 0.0 & 10 & 45.5 & 2 & 9.1 & 0 & 0.0 & & \\
\hline $\begin{array}{l}\text { 4. My mouth feels } \\
\text { dry. }\end{array}$ & 4 & 18.2 & 0 & 0.0 & 8 & 36.4 & 2 & 9.1 & 8 & 36.4 & 13 & 59.1 & 1 & 4.5 & 5 & 22.7 & 3 & 13.6 & 0 & 0.0 & & \\
\hline $\begin{array}{l}\text { 5. I have difficulty } \\
\text { in eating dry foods. }\end{array}$ & 4 & 18.2 & 0 & 0.0 & 7 & 31.8 & 0 & 0.0 & 11 & 50.0 & 12 & 54.5 & 0 & 0.0 & 8 & 36.4 & 2 & 9.1 & 0 & 0.0 & & \\
\hline $\begin{array}{l}\text { 6. I suck sweets or } \\
\text { cough lollies to } \\
\text { relieve dry mouth. }\end{array}$ & 5 & 22.7 & 1 & 4.5 & 4 & 18.2 & 1 & 4.5 & 11 & 50.0 & 9 & 40.9 & 1 & 4.5 & 9 & 40.9 & 2 & 9.1 & 1 & 4.5 & & \\
\hline $\begin{array}{l}\text { 7.have difficulties } \\
\text { swallowing certain } \\
\text { foods }\end{array}$ & 3 & 13.6 & 0 & 0.0 & 8 & 36.4 & 1 & 4.5 & 10 & 45.5 & 12 & 54.5 & 0 & 0.0 & 7 & 31.8 & 2 & 9.1 & 1 & 4.5 & & \\
\hline $\begin{array}{l}\text { 8. The skin of my } \\
\text { face feels dry. }\end{array}$ & 10 & 45.5 & 0 & 0.0 & 6 & 27.3 & 2 & 9.1 & 4 & 18.2 & 13 & 59.1 & 0 & 0.0 & 8 & 36.4 & 0 & 0.0 & 1 & 4.5 & & \\
\hline $\begin{array}{l}\text { 9. My eyes feel } \\
\text { dry. }\end{array}$ & 10 & 45.5 & 0 & 0.0 & 9 & 40.9 & 1 & 4.5 & 2 & 9.1 & 12 & 54.5 & 0 & 0.0 & 9 & 40.9 & 0 & 0.0 & 1 & 4.5 & & \\
\hline $\begin{array}{l}\text { 10. My lips feel } \\
\text { dry. }\end{array}$ & 1 & 4.5 & 1 & 4.5 & 12 & 54.5 & 3 & 13.6 & 5 & 22.7 & 10 & 45.5 & 0 & 0.0 & 11 & 50.0 & 0 & 0.0 & 1 & 4.5 & & \\
\hline $\begin{array}{l}\text { 11. The inside of } \\
\text { my nose feels dry. }\end{array}$ & 10 & 45.5 & 0 & 0.0 & 7 & 31.8 & 2 & 9.1 & 3 & 13.6 & 15 & 68.2 & 0 & 0.0 & 7 & 31.8 & 0 & 0.0 & 0 & 0.0 & & \\
\hline Total score ** $^{(55)}$ & & & & & & & & & & & & & & & & & & & & & 8.895 & $0.003^{*}$ \\
\hline Mean\% $\% S D$ & 35.8 & 11.821 & & & & & & & & & 22.27 & 10.973 & & & & & & & & & & \\
\hline
\end{tabular}

*: Statistically significant at $p \leq 0.05 \quad$ **: Lower mean indicate better condition

ASNJ Vol.21 N0.2, 2019 
Licorice Mouthwash, Xerostomia

Table (6): Distribution of the studied subjects (control group) according to their Xerostomia Inventory assessment findings based on Xerostomia Inventory assessment tool (n 22)

\begin{tabular}{|c|c|c|c|c|c|c|c|c|c|c|c|c|c|c|c|c|c|c|c|c|c|c|}
\hline \multirow{3}{*}{$\begin{array}{l}\text { Xerostomia } \\
\text { Inventory } \\
\text { Assessment Items }\end{array}$} & \multicolumn{10}{|c|}{$1^{\text {st }}$ day (Baseline Assessment) } & \multicolumn{10}{|c|}{$5^{\text {th }}$ day (Follow-up) } & \multicolumn{2}{|c|}{$\begin{array}{c}\text { Test of } \\
\text { significance }\end{array}$} \\
\hline & \multicolumn{2}{|c|}{$\begin{array}{c}(1) \\
\text { Never }\end{array}$} & \multicolumn{2}{|c|}{$\begin{array}{c}(2) \\
\text { 'Hardly } \\
\text { ever' }\end{array}$} & \multicolumn{2}{|c|}{$\begin{array}{c}(3) \\
\text { 'Occasional } \\
\text { ly' }\end{array}$} & \multicolumn{2}{|c|}{$\begin{array}{c}\text { (4) } \\
\text { 'Fairly } \\
\text { often' }\end{array}$} & \multicolumn{2}{|c|}{$\begin{array}{c}(\mathbf{5}) \\
\text { 'Very } \\
\text { often' }\end{array}$} & \multicolumn{2}{|c|}{$\begin{array}{l}(1) \\
\text { Never }\end{array}$} & \multicolumn{2}{|c|}{$\begin{array}{c}(2) \\
\text { 'Hardly } \\
\text { ever' }\end{array}$} & \multicolumn{2}{|c|}{$\begin{array}{c}(3) \\
\text { 'Occasional } \\
\text { ly' }\end{array}$} & \multicolumn{2}{|c|}{$\begin{array}{c}\text { (4) } \\
\text { 'Fairly } \\
\text { often' }\end{array}$} & \multicolumn{2}{|c|}{$\begin{array}{l}(\mathbf{5}) \\
\text { 'Very } \\
\text { often' }\end{array}$} & \multirow[t]{2}{*}{$\begin{array}{l}\text { Fried- } \\
\text { man } \\
\text { test }\end{array}$} & \multirow[t]{2}{*}{$\begin{array}{c}\mathrm{P} \\
\text { value }\end{array}$} \\
\hline & No & $\%$ & No & $\%$ & $\mathrm{~N}_{0}$ & $\%$ & $\mathrm{~N}_{0}$ & $\%$ & No & $\%$ & No & $\%$ & $\mathrm{~N}_{0}$ & $\%$ & No & $\%$ & $\mathrm{~N}_{0}$ & $\%$ & $\mathrm{~N}_{0}$ & $\%$ & & \\
\hline $\begin{array}{l}\text { 1. I sip liquids to } \\
\text { aid in swallowing } \\
\text { food. }\end{array}$ & 5 & 22.7 & 0 & 0.0 & 2 & 9.1 & 1 & 4.5 & 14 & 63.6 & 5 & 22.7 & 0 & 0.0 & 2 & 9.1 & 1 & 4.5 & 14 & 63.6 & & \\
\hline $\begin{array}{l}\text { 2. My mouth feels } \\
\text { dry when eating a } \\
\text { meal. }\end{array}$ & 3 & 13.6 & 0 & 0.0 & 4 & 18.2 & 1 & 4.5 & 14 & 63.6 & 3 & 13.6 & 0 & 0.0 & 4 & 18.2 & 1 & 4.5 & 14 & 63.6 & & \\
\hline $\begin{array}{l}\text { 3. Get up at night } \\
\text { to drink. }\end{array}$ & 0 & 0.0 & 1 & 4.5 & 3 & 13.6 & 3 & 13.6 & 15 & 68.2 & 0 & 0.0 & 1 & 4.5 & 3 & 13.6 & 3 & 13.6 & 15 & 68.2 & & \\
\hline $\begin{array}{l}\text { 4. My mouth feels } \\
\text { dry. }\end{array}$ & 3 & 13.6 & 0 & 0.0 & 5 & 22.7 & 1 & 4.5 & 13 & 59.1 & 3 & 13.6 & 0 & 0.0 & 5 & 22.7 & 1 & 4.5 & 13 & 59.1 & & \\
\hline $\begin{array}{l}\text { 5. I have difficulty } \\
\text { in eating dry foods. }\end{array}$ & 3 & 13.6 & 0 & 0.0 & 8 & 36.4 & 1 & 4.5 & 10 & 45.5 & 3 & 13.6 & 0 & 0.0 & 8 & 36.4 & 1 & 4.5 & 10 & 45.5 & & \\
\hline $\begin{array}{l}\text { 6. I suck sweets or } \\
\text { cough lollies to } \\
\text { relieve dry mouth. }\end{array}$ & 5 & 22.7 & 0 & 0.0 & 4 & 18.2 & 1 & 4.5 & 12 & 54.5 & 5 & 22.7 & 0 & 0.0 & 4 & 18.2 & 1 & 4.5 & 12 & 54.5 & & \\
\hline $\begin{array}{l}\text { 7.have difficulties } \\
\text { swallowing certain } \\
\text { foods }\end{array}$ & 5 & 22.7 & 0 & 0.0 & 6 & 27.3 & 1 & 4.5 & 10 & 45.5 & 5 & 22.7 & 0 & 0.0 & 7 & 31.8 & 1 & 4.5 & 9 & 40.9 & & \\
\hline $\begin{array}{l}\text { 8. The skin of my } \\
\text { face feels dry. }\end{array}$ & 15 & 68.2 & 0 & 0.0 & 4 & 18.2 & 0 & 0.0 & 3 & 13.6 & 16 & 72.7 & 0 & 0.0 & 3 & 13.6 & 0 & 0.0 & 3 & 13.6 & & \\
\hline $\begin{array}{l}\text { 9. My eyes feel } \\
\text { dry. }\end{array}$ & 17 & 77.3 & 1 & 4.5 & 2 & 9.1 & 0 & 0.0 & 2 & 9.1 & 16 & 72.7 & 1 & 4.5 & 3 & 13.6 & 0 & 0.0 & 2 & 9.1 & & \\
\hline $\begin{array}{l}\text { 10. My lips feel } \\
\text { dry. }\end{array}$ & 3 & 13.6 & 0 & 0.0 & 14 & 63.6 & 0 & 0.0 & 5 & 22.7 & 4 & 18.2 & 0 & 0.0 & 13 & 59.1 & 0 & 0.0 & 5 & 22.7 & & \\
\hline $\begin{array}{l}\text { 11. The inside of } \\
\text { my nose feels dry. }\end{array}$ & 17 & 77.3 & 0 & 0.0 & 4 & 18.2 & 0 & 0.0 & 1 & 4.5 & 17 & 77.3 & 0 & 0.0 & 4 & 18.2 & 0 & 0.0 & 1 & 4.5 & & \\
\hline Total score ** $^{(\mathbf{5 5})}$ & & & & & & & & & & & & & & & & & & & & & 1.00 & 0.317 \\
\hline Mean\% $\% S D$ & 35.4 & +11.63 & & & & & & & & & & 11.53 & & & & & & & & & & \\
\hline
\end{tabular}

*: Statistically significant at $p \leq 0.05$

**: Lower mean indicate better condition

ASNJ Vol.21 N0.2, 2019 
Table (7): Distribution of the studied subjects according to their mean percent score and standard deviation of their Xerostomia Inventory assessment findings based on Xerostomia Inventory assessment tool

\begin{tabular}{|c|c|c|c|c|c|c|c|c|}
\hline \multirow{3}{*}{$\begin{array}{l}\text { Xerostomia } \\
\text { Inventory } \\
\text { Assessment } \\
\text { Items ** }\end{array}$} & \multicolumn{2}{|c|}{ Study group n(22) } & \multicolumn{2}{|c|}{ Control group n(22) } & \multicolumn{4}{|c|}{ Test of significance } \\
\hline & $\begin{array}{c}\mathbf{1}^{\text {st }} \text { day } \\
\text { (Baseline } \\
\text { Assessment) } \\
\text { Scores }\end{array}$ & $\begin{array}{c}5^{\text {th }} \text { day } \\
\text { (Follow-up) } \\
\text { Scores }\end{array}$ & $\begin{array}{c}\mathbf{1}^{\text {st }} \text { day } \\
\text { (Baseline } \\
\text { Assessment) } \\
\text { Scores }\end{array}$ & $\begin{array}{c}5^{\text {th }} \text { day } \\
\text { (Follow-up) } \\
\text { Scores }\end{array}$ & & & & \\
\hline & Mean\% $\%$ SD & Mean\% \pm SD & Mean\% \pm SD & Mean\% $\%$ SD & P1 & P 2 & P 3 & P 4 \\
\hline $\begin{array}{l}\text { 1. I sip liquids } \\
\text { to aid in } \\
\text { swallowing } \\
\text { food. }(5)^{* *}\end{array}$ & $3.23 \pm 1.631$ & $1.95 \pm 1.214$ & $3.86 \pm 1.699$ & $3.86 \pm 1.699$ & $0.003 *$ & 1.00 & 0.307 & $<0.001 *$ \\
\hline $\begin{array}{l}\text { 2. My mouth } \\
\text { feels dry when } \\
\text { eating a meal. } \\
\text { (5)** }\end{array}$ & $3.55 \pm 1.595$ & $2.09 \pm 1.151$ & $4.05 \pm 1.463$ & $4.05 \pm 1.463$ & $0.002 *$ & 1.00 & 0.212 & $<0.001^{*}$ \\
\hline $\begin{array}{l}\text { 3. Get up at } \\
\text { night to drink. } \\
(5)^{* *}\end{array}$ & $4.00 \pm 1.309$ & $2.18 \pm 1.140$ & $4.45 \pm 0.912$ & $4.45 \pm 0.912$ & $<0.001^{*}$ & 1.00 & 0.179 & $<0.001 *$ \\
\hline $\begin{array}{l}\text { 4. My mouth } \\
\text { feels dry. } \\
(5)^{* *}\end{array}$ & $3.45 \pm 1.471$ & $1.91 \pm 1.192$ & $3.95 \pm 1.463$ & $3.95 \pm 1.463$ & $0.002 *$ & 1.00 & 0.307 & $<0.001 *$ \\
\hline $\begin{array}{l}\text { 5. I have } \\
\text { difficulty in } \\
\text { eating dry } \\
\text { foods. }(5)^{* *}\end{array}$ & $3.64 \pm 1.560$ & $2.00 \pm 1.155$ & $3.68 \pm 1.427$ & $3.68 \pm 1.427$ & $<0.001^{*}$ & 1.00 & 0.910 & $<0.001 *$ \\
\hline $\begin{array}{l}6 . \text { I suck } \\
\text { sweets or } \\
\text { lollies to } \\
\text { relieve dry } \\
\text { mouth. }(5)^{* *}\end{array}$ & $3.55 \pm 1.683$ & $2.32 \pm 1.249$ & $3.68 \pm 1.673$ & $3.68 \pm 1.673$ & $0.018 *$ & 1.00 & 0.787 & $0.004 *$ \\
\hline $\begin{array}{l}\text { 7. I have } \\
\text { difficulties } \\
\text { swallowing } \\
\text { certain foods. } \\
(5)^{* *}\end{array}$ & $3.68 \pm 1.427$ & $2.09 \pm 1.306$ & $3.50 \pm 1.626$ & $3.41 \pm 1.593$ & $<0.001 *$ & 0.317 & 0.696 & $0.001 *$ \\
\hline $\begin{array}{l}\text { 8. The skin of } \\
\text { my face feels } \\
\text { dry. }(5)^{* *}\end{array}$ & $2.55 \pm 1.595$ & $1.91 \pm 1.192$ & $1.91 \pm 1.477$ & $1.82 \pm 1.468$ & 0.248 & 0.317 & 0.204 & 0.803 \\
\hline $\begin{array}{l}\text { 9. My eyes } \\
\text { feel dry. (5)** }\end{array}$ & $2.32 \pm 1.359$ & $2.00 \pm 1.195$ & $1.59 \pm 1.260$ & $1.68 \pm 1.287$ & 0.527 & 0.317 & 0.084 & 0.259 \\
\hline $\begin{array}{l}\text { 10.My lips } \\
\text { feel dry. (5)** }\end{array}$ & $3.45 \pm 1.057$ & $2.18 \pm 1.181$ & $3.18 \pm 1.220$ & $3.09 \pm 1.306$ & $0.020 *$ & 0.317 & 0.466 & $0.029 *$ \\
\hline $\begin{array}{l}\text { 11. The inside } \\
\text { of my nose } \\
\text { feels dry. } \\
(5)^{* *}\end{array}$ & $2.45 \pm 1.503$ & $1.64 \pm .953$ & $1.55 \pm 1.101$ & $1.55 \pm 1.101$ & $0.034 *$ & 1.00 & $0.045^{*}$ & 0.803 \\
\hline $\begin{array}{l}\text { Total score } \\
(55)^{* *}\end{array}$ & $35.86 \pm 11.821$ & $22.27 \pm 10.973$ & $35.41 \pm 11.632$ & $35.23 \pm 11.538$ & $0.003 *$ & 0.317 & 0.904 & $<0.001 *$ \\
\hline
\end{tabular}

$p_{1}$ : Stands for p-value for Friedman test for comparison between $1^{\text {st }}$ day base line assessment with $5^{\text {th }}$ day follow-up assessment in the study group

$p_{2}$ : Stands for p-value for Friedman test for comparison between $1^{\text {st }}$ day base line assessment with $5^{\text {th }}$ day follow-up assessment in the control group

$p_{3}: p$ value for Student t-test for comparing $1^{\text {st }}$ day base line assessment between study and control group

$p_{4}$ : $p$ value for Student $t$-test for comparing $5^{\text {th }}$ day follow-up assessment between study and control group

*: Statistically significant at $p \leq 0.05 \quad$ **: Lower mean indicate better condition 


\section{References}

1. Casper P. End Stage Renal Disease: The Oral Component Saliva, Thirst and Oral Health in Patients on Renal Replacement Therapy. International Dental Journal 2005; 54: 143-148.

2. Hinkle J, Cheever K. Brunner and Suddarth's Text Book of Medical Surgical Nursing.10th ed. Philadelphia: Lippincott Williams and Wilkins, 2014; 1285-90.

3. Fan W, Zhang Q, Li-Hong L. Study on the Clinical Significance and Related Factors of Thirst and Xerostomia in Maintenance Hemodialysis Patients. Kidney Blood Pressure Research Journal 2013; 37:464-474.

4. Casper P, Henk S, Enno C. Interdialytic Weight Gain In Patients On Hemodialysis Is Associated With Dry Mouth And Thirst. Kidney International Journal 2004; 66(4):1662-8.

5. Joel J. Michael T. Philip C. Diagnosis and Treatment of Xerostomia (Dry Mouth). Journal of Odontology 2009; 97:76-83.

6. Gavião M, Bilt A. Salivary Secretion and Chewing: Stimulatory Effects from Artificial and Natural Foods. Journal Of Applied Oral Science 2004; 12(2):159-63

7. Stipetić M. Xerostomia - Diagnosis and Treatment. Journal of Medical Sciences, 2012; 38(1): 69-91.

8. Chen Y, Yun T, Ji F. Effects of Mouthwash Interventions on Xerostomia and Unstimulated Whole Saliva Flow Rate among Hemodialysis Patients: A Randomized Controlled Study. International Journal of Nursing Studies 2016; 63:917.

9. Villa A, Connell C, Abati S. Diagnosis and Management of Xerostomia and Hypo Salivation. Therapeutics and Clinical Risk Management Journal 2015; 11: 45-51.

10. Messier C, Epifano F, Genovese S. Licorice and Its Potential Beneficial Effects in Common Oro-Dental Diseases .Journal of Oral Diseases, 2012; 18(1):329.

11. Napeñas J, Michael T,Philip C. Diagnosis and Treatment of Xerostomia (dry mouth). Journal of Odontology 2009; 97:76-83.

12. Messier C, Epifano F, Genovese S. Licorice and its Potential Beneficial Effects in Common Orodental Diseases. Journal of Oral Diseases 2012; 18(1): 32-39

13. Lakshmi T, Geetha R. Glycyrrhiza Glabra Linn Commonly Known as Licorice: A Therapeutic Review. International Journal of Pharmacy and Pharmaceutical Sciences 2011; 3(4):20-25.

14. Hassan K, Khalil s. Liquorice Mouth Wash as Treatment for Mouth Ulcer. An International Journal of Advances in Pharmaceutical Sciences 2013; 4(3):335-340.

15. Crampton L. Licorice Root for Tooth Decay, Gum Disease, and Oral Health. Oral Health Journal 2017. Available at: https://healdove.com/oral-health/Licorice-RootFor-Tooth-Decay-and-Gum-Disease-Benefitsand-Dangers. Retrieved on: (18/12/2017).

16. Murphy A. Oral Hygiene Priority of Care 2012. Available
https://www.inmo.ie/Article/PrintArticle/2764. Retrieved on: (26/10/2017).

17. Elsayed H. Effect of implementing a protocol of nursing care on postoperative expected outcomes for patients undergoing intervertebral lumbar disc herniation surgeries. Unpublished Doctoral Dissertation, Faculty of Nursing, Alexandria University, 2015.

18. Thomson W. Chalmer J. Spence A. The Xerostomia Inventory: A multi-Item Approach to Measuring Dry Mouth. Community Dental Health 1999; 16(2): 12-17.

19. Song I, Wang J, Li M. Validation of the Chinese Version of the Summated Xerostomia Inventory (SXI). Journal of Quality Life Research 2013, 22:2843-2847.

20. Chalmers J, King P, Spencer A. The Oral Health Assessment Tool - Validity and reliability. Australian Dental Journal 2005; 50(3):191-199.

21. Yang w, Hwang s. Incidence, Prevalence and Mortality Trends of Dialysis End-Stage Renal Disease in Taiwan from 1990 to 2001: The Impact of National Health Insurance. Nephrology Dial Transplant 2008; 23: 3977-3982.

22. Bossola M, Tazza L. Xerostomia in Patients on Chronic Hemodialysis. Journal of Nephrology 2012; 8: 176-182.

23. Carrero J. Gender Differences in Chronic Kidney Disease: Underpinnings and Therapeutic Implications. Kidney Blood Pressure Research Journal 2010; 33:383-392.

24. Iseki K. Gender Differences in Chronic Kidney Disease. Journal of Kidney International 2008; 74: 415-417.

25. Shortridge E, James C. Marriage and End stage Renal Disease: Implications for African Americans. Journal of Family Issues 2010; 31(9): 1230-1249.

26. Adjei D, Stronks K. Relationship between Educational and Occupational Levels, And Chronic Kidney Disease in A Multi-Ethnic Sample- The HELIUS Study 2017. Available at: http://journals.plos.org/plosone/article?id=10.137 1/journal.pone.0186460. Retrieved on: (26/10/2017).

27. Rodriguez R, Hotchkiss J, Hare A. Geographic Information Systems and Chronic Kidney Disease: Racial Disparities, Rural Residence and Forecasting. Journal of Nephrology 2013; 26(1): 3-15.

28. Monhart V. Hypertension and Chronic Kidney Diseases. Education In Cardiology ELSIVER 2013.

29. Tedla F, Brar A, Browne R. Hypertension in Chronic Kidney Disease: Navigating the Evidence. International Journal of Hypertension 2011; 298(17):2038-47.

30. Touyz L. Liquorice Health Check, Oro-Dental Implications, and a Case Report. 2009. Available at:

https://www.ncbi.nlm.nih.gov/pmc/articles/PMC2 729489/. Retrieved on: (10/9/2017). 